\title{
Spatial Variability of the Physical and Mineralogical Properties of the Soil from the Areas with Variation in Landscape Shapes
}

\author{
Zigomar Menezes de Souza ${ }^{1 *}$, José Marques Júnior ${ }^{2}$ and Gener Tadeu Pereira ${ }^{3}$ \\ ${ }^{1}$ Faculdade de Engenharia Agrícola; Universidade Estadual de Campinas; Cidade Universitária Zeferino Vaz; CP \\ 6011; 13083-875; Campinas - SP - Brasil. ${ }^{2}$ Departamento de Solos e Adubos; Universidade Estadual Paulista; \\ 14884-900; Jaboticabal - SP - Brasil. ${ }^{3}$ Departamento de Ciências Exatas; Universidade Estadual Paulista; 14884 - \\ 900; Jaboticabal - SP - Brasil
}

\begin{abstract}
The objective of this work it was to use the geostatistics methods to investigate the spatial relationships between the physical and mineralogical properties of an oxisol planted with the sugarcane in an area of slight variations in the landform. The soil was sampled at $10 \mathrm{~m}$ regular intervals in the crossing points of a $100 \times 100 \mathrm{~m}$ grid. At each point, the soil was collected at 0.0-0.2 m, 0.2-0.4 $\mathrm{m}$ and 0.4-0.6 $\mathrm{m}$ depths for the analyzes of physical properties and at 0.6-0.8 $\mathrm{m}$ for the mineralogical analyses. Both the $\mathrm{Kt} / \mathrm{Kt}+\mathrm{Gb}$ ratio and $\mathrm{Kt}$ relative crystallization level were higher in the compartment I than in the compartment II. As a consequence, the soil penetration resistance and bulk density were higher in the compartment I, while the macroporosity and Ksat were lower. Therefore, it was concluded that both the identification and mapping of a landform were efficient for understanding the spatial variability of the soil properties. Moreover, variations in the landscape shape promoted the differentiated variability of the physical and mineralogical soil properties: the more variable the landscape, the more variable was the soil properties.
\end{abstract}

Key Words: Sugarcane, geostatistics, soil-landscape relationship

\section{INTRODUCTION}

Modern agriculture should be based on both the sustained natural resources and optimization of the land use, thus avoiding the degradation of the soil structure and of the environment. However, the modernization and mechanization of the sugarcane crops in Brazil has altered soil the physical properties and crop productivity. The quality of the soil structure has been associated with the physical conditions that promote the root growth, aeration, water entrance into the soil, and water movement through the soil profile. Therefore, the main harms to the soils are evidenced by the increased mechanical resistance to the root penetration and bulk density, reduction of the aeration and modification of water availability and flow (Utset and Cid, 2001).

The physical properties of the soil show wide variations along a landscape. The complex geological and pedological processes such as the soil formation factors, parent materials, weather and topography are the main causes of the natural soil variability. Thus, this variability occurs since the soil formation and continues even after the achievement of a dynamic equilibrium. However,

\footnotetext{
*Author for correspondence: zigomarms@agr.unicamp.br
} 
the management practices on the soils also affect significantly the soil variability (Castrignanò et al., 2000), especially as a result of the successive agricultural activities and erosion.

As the soils from the agriculture activities are heterogeneous, the analyses of the landscape (Bouma et al., 1999) and of the topographic position of the study area are necessary for an adequate determination of the management of the agriculture zones. The landscape position and soil slope generate a complex pattern of the water and solute transport that influences the development of the soil profile. Thus, the soil physical properties affect the water movement temporally and spatially (Strock et al., 2001).

Geostatistics has been applied increasingly in the soil science for the study of the spatial variability. It is becoming an additional tool for the investigation of the soil properties that are spatially correlated, mainly because it enables the study of the spatial variability, i.e., analyses of the results are based on variability structure. In Brazil, the studies on the spatial variability of the physical and mineralogical properties associated with the landscape are still scarce, where the oxisols present the widest geographical occurrence and are largely used for the sugarcane planting. These soils show high structural stability and strong granular structure mainly due to the iron. Kaolinite, gibbsite, goethite and hematite in variable proportions are the major mineral components of the clay fraction in the Brazilian oxisols (Ferreira et al., 1999).

In this context, the present study used the geostatistics methods to investigate the spatial relationships between the physical and mineralogical properties of an oxisol planted with the sugarcane in an area of slight variations in the landform.

\section{MATERIALS AND METHODS}

\section{Study Area and Sampling Units}

This study was carried out in Oxisol at Guariba, SP (elevation $640 \mathrm{~m} ; 21^{\circ} 19^{\prime} \mathrm{S}, 48^{\circ} 13^{\prime} \mathrm{W}$ ). The area climate is categorized as Cwa in the Köppen classification, and the mean annual precipitation is $1400 \mathrm{~mm}$, with rain concentrated from November to February. The relief of the study area was soft wavy with 3 to $8 \%$ slope. The sugarcane crop from the experimental area was older than 30 years.
The curvature and profile of the landforms in the lowest $1 / 3$ hillslope were classified according to Troeh (1965)'s model in: relief-shaped basically linear (compartment I) and concave- and convexshaped relief (compartment II), (Fig. 1). The soil samplings were taken at $10-\mathrm{m}$ regular intervals in the crossing points of a $100 \times 100 \mathrm{~m}$ grid totaling 1 ha. A furrow $(0.3 \times 0.3 \mathrm{~m} ; 0.6 \mathrm{~m}$ depth $)$ was opened at each sampling point and the soil was collected at 0.0-0.2 m, 0.2-0.4 m and 0.4-0.6 m depths for the physical properties analyses and at 0.6-0.8 $\mathrm{m}$ for the mineralogical properties analyses. One hundred points were georeferenced for each sampling depth.

\section{Physical Properties}

The determination of the clay, silt and sand was achieved by the pipette method using $0.1 \mathrm{~N}$ as a dispersing agent and stirring the solution at low speed for $16 \mathrm{~h}$ as proposed by Embrapa (1997). The constant infiltration rate and field-saturated hydraulic conductivity (Ksat) were measured according to Reynolds and Elrick (1985). The soil penetration resistance was measured by an impact penetrometer (Stolf, 1991). Undisturbed samples were collected with the volumetric rings for the macroporosity determination in a tension table. The same samplings were used for the bulk density determination by the 'known volume' method (Embrapa, 1997).

\section{Mineralogical Properties}

The gibbsite $(\mathrm{Gb})$-kaolinite (Kt) system was determined in the non-ferric clay fraction submitted to X-ray powder diffraction (XRD). The XRD analyses were conducted using a HZG - 4/B diffractometer with copper cathode, nickel filter, $\mathrm{K} \alpha$ radiation $(20 \mathrm{~mA}, 30 \mathrm{Kv})$ and scanning speed of $1^{\circ} 2 \theta / \mathrm{min}$. The $\mathrm{Kt} /(\mathrm{Kt}+\mathrm{Gb})$ ratio was calculated by $\mathrm{Kt}(001)$ and $\mathrm{Gb}(002)$ reflections plane areas. These reflections positions were used along with $\mathrm{Kt}$ and $\mathrm{Gb}$ width at half height (WHH) to calculate the mean crystallites diameter (MCD) by the Scherrer equation (Schulze, 1984).

\section{Geostatistical Procedures}

The soil variability was firstly assessed by the exploratory analyses (mean, median, coefficient of variation, skewness and kurtosis). The normality was tested by the Kolmogorov-Smirnov's test by SAS program (Schlotzhaver and Littell, 1997). Using the regionalized variable theory, the spatial variation was calculated by the semivariogram 
method (Journel and Huijbregts, 1991), which assumed the stationarity and the intrinsic hypothesis and expressed by:

$$
\gamma(h)=\frac{1}{2} E\left[Z\left(x_{i}\right)-Z\left(x_{i}+h\right)\right]^{2},
$$

which is a function of the vector $h$ and thus depends on the magnitude and direction $h$. The semivariance was estimated by the expression:

$$
\hat{\gamma}(h)=\frac{1}{2 N(h)} \sum_{i=1}^{N(h)}\left[Z\left(x_{i}\right)-Z\left(x_{i}+h\right)\right]^{2} \text {, }
$$

where $\mathrm{N}(\mathrm{h})$ is the pair number of measured points $\mathrm{Z}\left(\mathrm{x}_{\mathrm{i}}\right), \mathrm{Z}\left(\mathrm{x}_{\mathrm{i}}+\mathrm{h}\right)$, separated by a vector $\mathrm{h}$. The graph plotted from $\hat{\gamma}(h)$ and the corresponding $\mathrm{h}$ values is called a semivariogram.

The theoretical model coefficients of the semivariogram (nugget effect, $\mathrm{C}_{0}$; sill, $\mathrm{C}_{0}+\mathrm{C}_{1}$; range, a) were determined by the fitness of the mathematical model for $\hat{\gamma}(h)$ values. The nugget effect was the separation distance from the value of 0 at the origin to the value of the semivariogram and represented the random variation component. The sill was the constant semivariance value where the curve was stabilized. The range was the distance from the origin to the plateau where the stable values were reached and beyond this level the samples were not associated with each other (Vieira et al., 1983). The following models were fitted to the data: (a) spherical (Sph), $\hat{\gamma}(h)=\mathrm{C}_{0}+$ $\mathrm{C}_{1}\left[1.5(\mathrm{~h} / \mathrm{a})-0.5(\mathrm{~h} / \mathrm{a})^{3}\right]$ for $0<\mathrm{h}<\mathrm{a}$ and $\hat{\gamma}(h)=$ $\mathrm{C}_{0}+\mathrm{C}_{1}$ for $\mathrm{h}>\mathrm{a}$; and (b) exponential (Exp), $\hat{\gamma}(h)$ $=\mathrm{C}_{0}+\mathrm{C}_{1}[1-\exp (-3 \mathrm{~h} / \mathrm{a})]$ for $0<\mathrm{h}<\mathrm{d}$, where $\mathrm{d}$ is the maximal distance for which the semivariogram is defined.

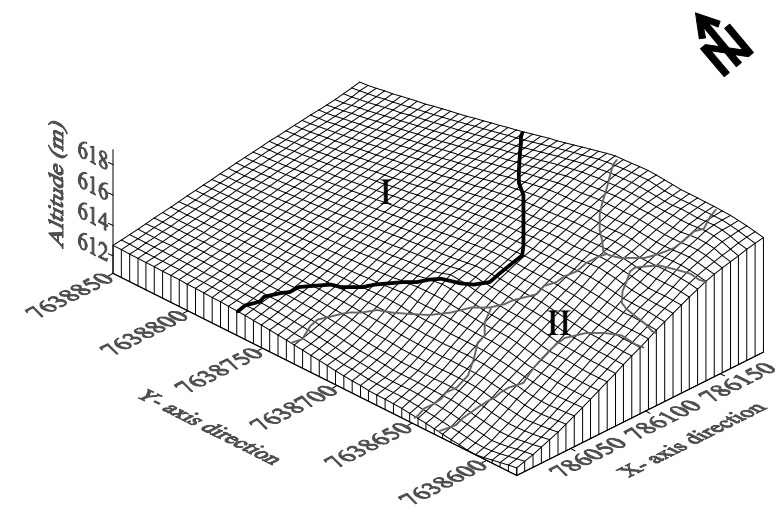

Figure 1 - Study area map. Compartments I (linear) and II (concave-convex) are identified.

For the spatial dependence determination, the semivariogram examination by the $\mathrm{GS}^{+}$program (Gamma Design Inc., Plainwell, MI) was employed. When more than one variogram was used, the most appropriate was chosen by the cross-validation ("jack-knifing") method. The Golden Software (Surfer, 1999) was used for plotting the spatial distribution maps of the variables. The spatial dependence of the investigated variables employed Cambardella et al. (1994)'s classification. Accordingly, the semivariograms with the nugget effect $\leq 25 \%$ signified that the variables were strongly spatially dependent, and the nugget effect $>75 \%$ indicated the variables weakly spatially dependent; intermediate values from $25 \%$ to $75 \%$ represented the moderate dependency.

\section{RESULTS AND DISCUSSION}

The descriptive statistics of the soil properties sampled in the study area (compartments I and II) are shown in Table 1 . The mean values of the granulometric and mineralogical properties were in accordance with the class of the studied soil. The soil saturated hydraulic conductivity (Ksat; Table 1) was classified as slow to moderate for 0.0-0.2 $\mathrm{m}$ depth, and slow for 0.2-0.4 $\mathrm{m}$ depth (Soil Survey Staff, 1993). The low water flow was a consequence of the intensive heavy machines running on the soil for the sugarcane management. The mean values found for the soil penetration resistance (Table 1) were high for $0.0-0.2 \mathrm{~m}$ and 0.4-0.6 m depths and very high for 0.2-0.4 m depths (Soil Survey Staff, 1993). Onofiok (1988) 
has also found that the penetration resistance increased in the deeper layers of the corn-planted soil. The penetration-resistance values between 2.0 and 4.0 MPa impair the crops (Arshad et al, 1996). Nevertheless, the values higher than 5.0 MPa, as found in the present study were also acceptable in the absence of the tillage (Ehlers et al., 1983). The soil analyzed here were more resistant to penetration probably because it was in the fifth crop harvest of the sugarcane and was not been turned over during this period. Dexter (1987) suggested that the problem of the soil compaction was increased in the dried soil, but when the soil water content was higher, the roots grows under the penetration resistance higher than 4.0 MPa.

The mean bulk density (Table 1), which ranged from 1.33 to $1.41 \mathrm{~kg} \mathrm{dm}^{-3}$, was also high according to Arshad et al. (1996), who reported that the values higher than $1.4 \mathrm{~kg} \mathrm{dm}^{-3}$ impair in the root growth in the clay soil. The high bulk density and resistance to penetration and the low soil permeability were associated with the intensive traffic in sugarcane crop. According to Salire et al. (1994) and Hakansson and Voorhees (1997), the soil compaction may reach $0.4 \mathrm{~m}$ depths when the soil was not turned over and the movement of the heavy machines took place.

Using the CV classification criterion proposed by Warrick and Nielsen (1980), the clay and sand presented low $\mathrm{CV}$ values at the three sampled depths and Silt CVs had average values (Table 1). The soil mineralogical properties had higher CVs at $0.4-0.6 \mathrm{~m}$ depth. For the saturated hydraulic conductivity, the Cvs were very high, but the literature has described values higher than $100 \%$ (Onofiok, 1988; Tsegaye and Hill, 1998). Warrick and Nielsen (1980) found CVs from 90 to $190 \%$ for the saturated hydraulic conductivity. The CVs of the soil resistance were high and the bulk density presented low $\mathrm{CV}$ values.

Table 1 - Descriptive and normality analyses of soil physical properties at different depths and mineralogical properties at 06-08 $\mathrm{m}$ depth.

\begin{tabular}{|c|c|c|c|c|c|c|}
\hline Soil Properties & Mean & Median & $\mathbf{C V}$ & Skewness & kurtosis & ${ }^{1} \mathbf{d}$ \\
\hline & \multicolumn{6}{|c|}{$0.0-0.2$} \\
\hline Clay $\left(\mathrm{g} \mathrm{kg}^{-1}\right)$ & 622 & 620 & 2.91 & -0.04 & -0.75 & 0.12 \\
\hline Silt $\left(\mathrm{g} \mathrm{kg}^{-1}\right)$ & 210 & 208 & 13.15 & -0.13 & -0.79 & $0.07^{*}$ \\
\hline Sand $\left(\mathrm{g} \mathrm{kg}^{-1}\right)$ & 168 & 169 & 7.37 & -0.26 & 1.45 & 0.14 \\
\hline${ }^{2}$ Hsat $\left(\mathrm{mm} \mathrm{h}^{-1}\right)$ & 30.11 & 24.17 & 68.73 & 0.36 & -1.21 & 0.20 \\
\hline Penetration Resistance (MPa) & 4.40 & 4.54 & 38.73 & -0.20 & -0.88 & $0.07^{*}$ \\
\hline Bulk Density $\left(\mathrm{kg} \mathrm{dm}^{-3}\right)$ & 1.38 & 1.40 & 5.45 & 0.13 & -0.53 & $0.04^{*}$ \\
\hline \multirow[t]{2}{*}{ Macroporosity $\left(\mathrm{m}^{3} \mathrm{~m}^{-3}\right)$} & 0.15 & 0.13 & 26.10 & 0.06 & -0.80 & $0.05^{*}$ \\
\hline & \multicolumn{6}{|c|}{$0.2-0.4$} \\
\hline Clay $\left(\mathrm{g} \mathrm{kg}^{-1}\right)$ & 637 & 636 & 3.97 & 0.10 & -0.87 & 0.15 \\
\hline Silt $\left(\mathrm{g} \mathrm{kg}^{-1}\right)$ & 200 & 201 & 12.41 & -0.05 & -0.84 & $0.08^{*}$ \\
\hline Sand $\left(\mathrm{g} \mathrm{kg}^{-1}\right)$ & 163 & 162 & 8.38 & -0.33 & -0.04 & $0.07^{*}$ \\
\hline Hsat $\left(\mathrm{mm} \mathrm{h}^{-1}\right)$ & 23.48 & 29.37 & 61.20 & 0.53 & -0.08 & 0.17 \\
\hline Penetration Resistance (MPa) & 5.11 & 5.06 & 28.12 & 0.30 & -0.19 & $0.06^{*}$ \\
\hline Bulk Density $\left(\mathrm{kg} \mathrm{dm}^{-3}\right)$ & 1.41 & 1.40 & 8.57 & 0.31 & 0.60 & $0.07^{*}$ \\
\hline \multirow[t]{2}{*}{ Macroporosity $\left(\mathrm{m}^{3} \mathrm{~m}^{-3}\right)$} & 0.13 & 0.11 & 32.21 & 0.01 & -0.31 & $0.04^{*}$ \\
\hline & \multicolumn{6}{|c|}{$0.4-0.6$} \\
\hline Clay $\left(\mathrm{g} \mathrm{kg}^{-1}\right)$ & 670 & 668 & 3.72 & -0.58 & 0.19 & 0.13 \\
\hline Silt $\left(\mathrm{g} \mathrm{kg}^{-1}\right)$ & 190 & 192 & 14.45 & -0.13 & -0.12 & $0.07^{*}$ \\
\hline Sand $\left(\mathrm{g} \mathrm{kg}^{-1}\right)$ & 140 & 141 & 10.35 & -0.07 & -0.29 & $0.06^{*}$ \\
\hline Penetration Resistance (MPa) & 3.10 & 3.25 & 29.12 & -0.18 & 0.01 & 0.16 \\
\hline Bulk Density $\left(\mathrm{kg} \mathrm{dm}^{-3}\right)$ & 1.33 & 1.31 & 6.29 & 0.35 & -0.45 & $0.07^{*}$ \\
\hline \multirow[t]{2}{*}{ Macroporosity $\left(\mathrm{m}^{3} \mathrm{~m}^{-3}\right)$} & 0.10 & 0.11 & 24.32 & $-0,07$ & -0.26 & $0.08^{*}$ \\
\hline & \multicolumn{6}{|c|}{$0.6-0.8$} \\
\hline $\mathrm{Kt} /{ }^{3} \mathrm{Kt}+{ }^{4} \mathrm{~Gb}$ & 0.55 & 0.56 & 26.52 & -0.50 & 0.54 & 0.15 \\
\hline${ }^{5} \mathrm{WHH}-\mathrm{Kt}\left({ }^{0} 2 \theta\right)$ & 0.52 & 0.51 & 26.02 & -0.06 & -0.23 & 0.16 \\
\hline $\mathrm{WHH}-\mathrm{Gb}\left({ }^{0} 2 \theta\right)$ & 0.21 & 0.20 & 24.45 & 0.53 & -0.71 & 0.18 \\
\hline${ }^{6} \mathrm{MCD}-\mathrm{Kt}(\mathrm{nm})$ & 252.46 & 241.37 & 25.24 & 0.91 & 0.87 & 0.15 \\
\hline $\mathrm{MCD}-\mathrm{Gb}(\mathrm{nm})$ & 6406.38 & 5371.65 & 36.26 & 0.88 & -0.66 & 0.23 \\
\hline
\end{tabular}

${ }^{1} \mathrm{~d}$ - Kolmogorov-Smirnov test, $\alpha-5 \% ;{ }^{2} \mathrm{Hsat}-$ field saturated hydraulic conductivity; ${ }^{3} \mathrm{Kt}-\mathrm{Kaolinite} ;{ }^{4} \mathrm{~Gb}-\mathrm{Gibbsite} ;{ }^{5} \mathrm{WHH}-$ width at half height; ${ }^{6} \mathrm{MCD}$ - mean crystallites diameter. 
The use of the $\mathrm{CV}$ categories is a common procedure to assess the soil spatial variability. However, this procedure must be restricted and directed to the purpose of the study, because it allows the comparison among the samples with different units of measurement. But the geostatistical techniques must be carried out for understanding the spatial dependence among the variables (Liu et al., 2006). These techniques, associated with the evaluation of the landscape characteristics, support technology transfer.

Data of the bulk density, macroporosity and silt in all the studied depths showed normal distribution (Table 1; Kolmogorov-Smirnov test). Data from the soil penetration resistance at $0.0-0.2 \mathrm{~m}$ and $0.2-$ $0.4 \mathrm{~m}$ and for the sand at $0.2-0.4$ and $0.4-0.6 \mathrm{~m}$ depths showed also normality for the distribution. The means were similar among them and symmetrically distributed, as were the medians, except for Ksat. According to Warrick and Nielsen
(1980), the soil mechanical properties have normal distribution while the hydraulic properties have non-normal distribution. But the 'proportional effect' rather than data normality should determine the adequacy of the data for the geostatistical analyses (Isaaks and Srivastava, 1989). In the present study, this effect was not observed and, thus, the data were stationary and geostatistics could be performed. However, because the data were from the field samples, the adjustment to the theoretical distribution was only approximated (Cressie, 1991).

The geostatistical analyses (Table 2) showed that all the variables were spatially dependent. Most of the estimated semivariance of the studied variables were fitted to a spherical model, except for the clay, silt, sand and bulk density at 0.2-0.4 $\mathrm{m}$ and silt, sand, macroporosity at $0.4-0.6 \mathrm{~m}$ and $\mathrm{Kt} / \mathrm{Kt}+\mathrm{Gb}$ at $0.6-0.8 \mathrm{~m}$ depths, which conformed to the exponential model.

Table 2 - Parameters for variogram models of soil properties at the different depths.

\begin{tabular}{|c|c|c|c|c|c|}
\hline Soil Properties & Model & $\operatorname{Nugget}\left(C_{0}\right)$ & Sill $\left(C_{0}+C_{1}\right)$ & range (a) & ${ }^{1}$ SDL \\
\hline & \multicolumn{5}{|c|}{$0.0-0.2$} \\
\hline Clay $\left(\mathrm{g} \mathrm{kg}^{-1}\right)$ & Spherical & 106 & 314 & 35 & 34 \\
\hline Silt $\left(\mathrm{g} \mathrm{kg}^{-1}\right)$ & Spherical & 123 & 457 & 41 & 27 \\
\hline Sand $\left(\mathrm{g} \mathrm{kg}^{-1}\right)$ & Spherical & 23 & 122 & 21 & 19 \\
\hline${ }^{2}$ Hsat $\left(\mathrm{mm} \mathrm{h}^{-1}\right)$ & Spherical & 21.70 & 77.72 & 16 & 28 \\
\hline Penetration Resistance (MPa) & Spherical & 0.09 & 0.96 & 20 & 9 \\
\hline Bulk Density $\left(\mathrm{kg} \mathrm{dm}^{-3}\right)$ & Spherical & 0.002 & 0.008 & 20 & 25 \\
\hline \multirow[t]{2}{*}{ Macroporosity $\left(\mathrm{m}^{3} \mathrm{~m}^{-3}\right)$} & Spherical & 0.0007 & 0.004 & 20 & 18 \\
\hline & Exponential & 264 & $\begin{array}{c}0.2-0.4 \\
528\end{array}$ & 45 & 50 \\
\hline Silt $\left(\mathrm{g} \mathrm{kg}^{-1}\right)$ & Exponential & 145 & 430 & 60 & 34 \\
\hline Sand $\left(\mathrm{g} \mathrm{kg}^{-1}\right)$ & Exponential & 31 & 110 & 30 & 27 \\
\hline${ }^{2}$ Hsat $\left(\mathrm{mm} \mathrm{h}^{-1}\right)$ & Spherical & 27.41 & 104.90 & 18 & 27 \\
\hline Penetration Resistance (MPa) & Spherical & 0.15 & 0.74 & 25 & 21 \\
\hline Bulk Density $\left(\mathrm{kg} \mathrm{dm}^{-3}\right)$ & Exponential & 0.001 & 0.005 & 59 & 20 \\
\hline \multirow[t]{2}{*}{ Macroporosity $\left(\mathrm{m}^{3} \mathrm{~m}^{-3}\right)$} & Spherical & 0.0002 & 0.001 & 26 & 20 \\
\hline & & & $0.4-0.6$ & & \\
\hline Clay $\left(\mathrm{g} \mathrm{kg}^{-1}\right)$ & Spherical & 10 & 615 & 19 & 2 \\
\hline Silt $\left(\mathrm{g} \mathrm{kg}^{-1}\right)$ & Exponential & 105 & 442 & 50 & 24 \\
\hline Sand $\left(\mathrm{g} \mathrm{kg}^{-1}\right)$ & Exponential & 45 & 189 & 21 & 24 \\
\hline Penetration Resistance (MPa) & Spherical & 0.05 & 0.24 & 21 & 21 \\
\hline Bulk Density $\left(\mathrm{kg} \mathrm{dm}^{-3}\right)$ & Spherical & 0.001 & 0.005 & 20 & 20 \\
\hline \multirow[t]{2}{*}{ Macroporosity $\left(\mathrm{m}^{3} \mathrm{~m}^{-3}\right)$} & Exponential & 0.0001 & 0.0005 & 30 & 20 \\
\hline & & & $0.6-0.8$ & & \\
\hline $\mathrm{Kt} / \mathrm{Kt}+\mathrm{Gb}$ & Exponential & 0.0007 & 0.004 & 23 & 18 \\
\hline${ }^{5} \mathrm{WHH}-{ }^{3} \mathrm{Kt}\left({ }^{0} 2 \theta\right)$ & Spherical & 0.0005 & 0.002 & 21 & 25 \\
\hline $\mathrm{WHH}-{ }^{4} \mathrm{~Gb}\left({ }^{0} 2 \theta\right)$ & Spherical & 0.0002 & 0.006 & 27 & 3 \\
\hline${ }^{6} \mathrm{MCD}-\mathrm{Kt}(\mathrm{nm})$ & Spherical & 128 & 2001 & 19 & 6 \\
\hline $\mathrm{MCD}-\mathrm{Gb}(\mathrm{nm})$ & Spherical & 66000 & 964000 & 21 & 7 \\
\hline
\end{tabular}


Chien et al. (1997) found the soil granulometric properties fitted to a Gaussian model. Utset and Cid (2001) studied the spatial variability of the soil penetration resistance and fitted the semivariograms of the bulk density and the soil penetration resistance to a spherical model. Cambardella et al. (1994) found that the semivariogram of the bulk density was adjusted by a spherical model; and Tsegaye and Hill (1998), evaluating the effect of intensive soil management on the variability of the soil properties, described a linear model fitted to the semivariograms for the bulk density and hydraulic conductivity. According to Trangmar et al. (1985), the study area scale exerted a great influence on the fitness of the soil properties to the mathematical models. In the present study, the spherical and exponential models fitted the data. Although the spherical model was predominant, both the models were the primary methods to adjust the soil physical properties in scientific works. Utset and $\mathrm{Cid}$ (2001) observed distinct patterns of the spatial variability of the soil penetration resistance for the dry and humid soil conditions. For the dry soil, these $\mathrm{CV}$ values were $25 \%$ and fitted the semivariogram by the spherical model, while for the humid soil CV was $80 \%$ and a pure nugget effect was obtained.

The nugget effect represents the random or unexplainable variance of the semivariogram, frequently caused by the errors in the measuring procedures or by the variation of the properties that cannot be detected in a sampling scale (Trangmar et al., 1985). In the semivariograms presented here for the physical and mineralogical properties, the high values for the nugget effect were not found because of the small lag distance between the sampling points. The behavior of the semivariogram parameters (sill and range) for the physical properties was similar among the depths and no significant changes in spatial dependence occurred.

The ratio $\mathrm{C}_{0} /\left(\mathrm{C}_{0}+\mathrm{C}_{1}\right)$ showed strong spatial dependence for all the variables, except for the clay and silt at 0.0-0.2 $\mathrm{m}$ and 0.2-0.4 m depth, for the sand at 0.2-0.4 m depth and for the hydraulic conductivity at all the depths studied. Cambardella et al. (1994) suggested that the spatial variability among the soil properties could be affected by the intrinsic and extrinsic factors commonly caused by soil management practices. In the present study, the spatial dependence identified for the physical and mineralogical properties was strongly related to landform.

The studied variables expressed different spatial dependence ranges (Table 2): the lowest value (16 $\mathrm{m})$ was found for the Ksat at 0.0-0.2 m depth and the highest $(60 \mathrm{~m})$ for the silt at $0.2-0.4 \mathrm{~m}$ depth. The physical properties were close to the range, oscillating between 16 and $30 \mathrm{~m}$ depth, except for the bulk density at $0.2-0.4 \mathrm{~m}$ depth and silt at all the depths; the range for the mineralogical properties were similar to each other.

The oxisol concept assumes that the soil profile traits have a relative homogeneity. Nevertheless, the variability of the physical and mineralogical properties found here showed that even the surface of the soil planted with the sugarcane for more than 30 years might not be homogeneous. At 0.4$0.6 \mathrm{~m}$ depth, all the variables showed variability, indicating that even the oxisols, traditionally considered homogeneous and highly weatherized, had the spatial variability of the physical and mineralogical properties of a horizon that was little affected by the soil management.

As the physical and mineralogical properties of the soil had a spatial structure, the parameters of the adjusted semivariogram models were used for estimating the values in the non- sampled areas by the kriging method (Figs. 2, 3, 4 and 5). These illustrated the spatial distribution of each physical and mineralogical property. The values of the kriging maps at 0.0-0.2 m depth ranged from 22 to $50 \mathrm{~mm} \mathrm{~h}^{-1}$ for the Ksat, 2.4 to $5.6 \mathrm{MPa}$ for the soil penetration resistance, 1.2 to $1.5 \mathrm{~kg} \mathrm{dm}^{-3}$ for the bulk density, and 0.05 to $0.21 \mathrm{~m}^{3} \mathrm{~m}^{-3}$ for the macroporosity. At $0.2-0.4 \mathrm{~m}$ depth, the kriging values ranged from 12 to $40 \mathrm{~mm} \mathrm{~h}^{-1}$ for the Ksat, 3.2 to $6.4 \mathrm{MPa}$ for the soil penetration resistance, 1.3 to $1.4 \mathrm{~kg} \mathrm{dm}^{-3}$ for the bulk density, and 0.04 to $0.20 \mathrm{~m}^{3} \mathrm{~m}^{-3}$ for the macroporosity (Fig. 2). At $0.2-$ $0.4 \mathrm{~m}$ soil depth penetration the resistance values were increased while the Ksat decreased. These effects were consequences of the sugarcane crop management that suffered from the excessive movement of the heavy machines and burn residues.

In the most elevated area showing a flat and linear profile (Compartment I), all the investigated variables had lower variability (Figs. 2, 3, 4 and 5). However, in the lower portion with the heterogeneous slope and relief shape (Compartment II), the physical and mineralogical properties showed higher variation. These results were in agreement with Bathke and Cassel (1991), 
Schoorl et al. (2002) and Zebarth et al. (2002), who also found association between the soil physical properties and landscape positions.

Geostatistics is an important tool for the comprehension of the variability of the soil properties which could be accomplished by the landscape model (Oldak et al., 2002) because the landscape position could affect significantly the physical soil properties and water transport. (Djurhuus et al., 1999; De Alba, 2003). The present study also supported this idea. Miller et al. (1988) found that the variation in the grain yield and chemical and physical properties of the soil associated with the landscape position were a function of the soil variability.
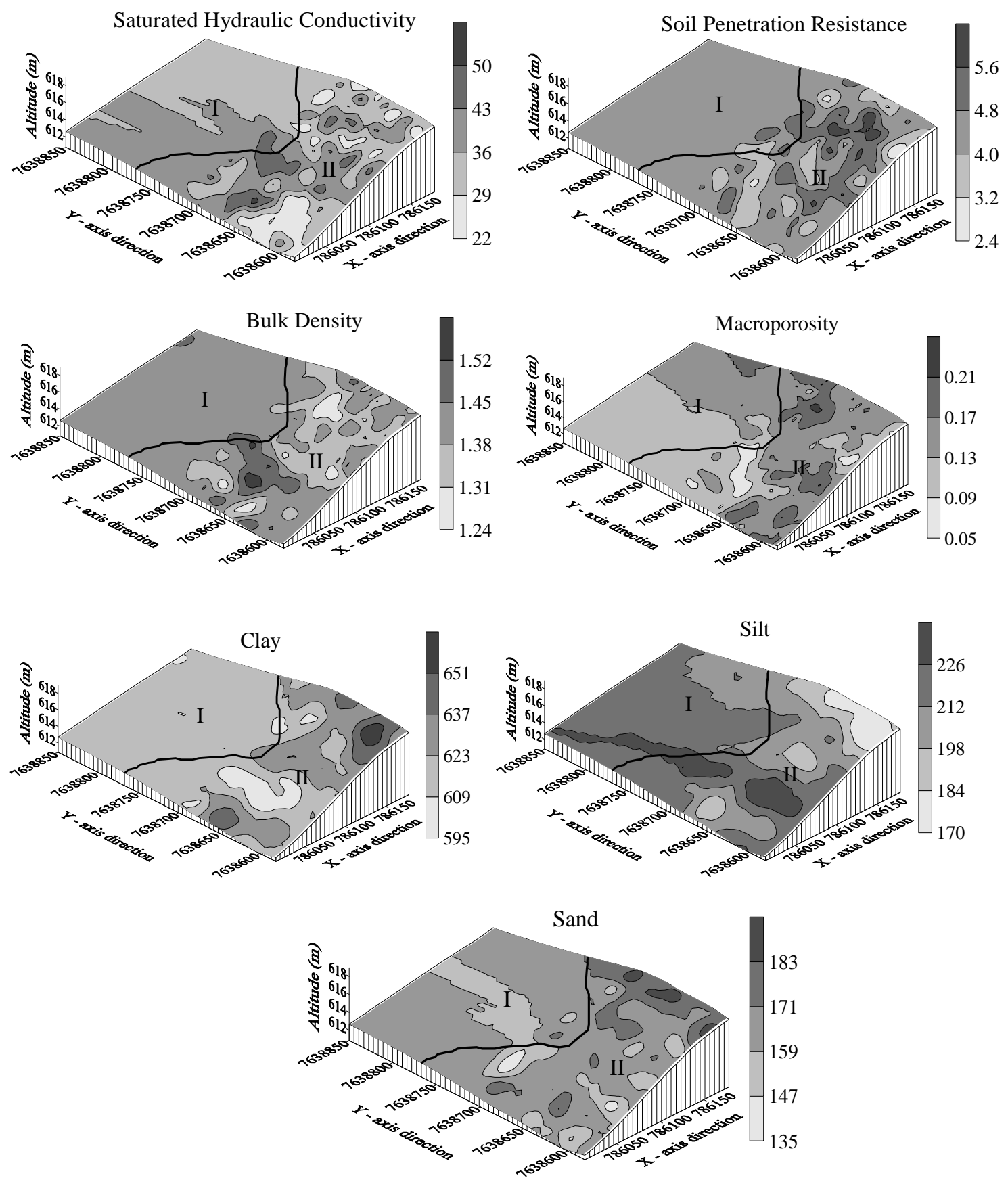

Figure 2 - Spatial distribution of soil physical properties at $0.0-0.2 \mathrm{~m}$ depth: clay, silt and sand $\left(\mathrm{g} \mathrm{kg}^{-1}\right)$; saturated hydraulic conductivity $\left(\mathrm{mm} \mathrm{h}^{-1}\right)$; penetration resistance (MPa); bulk density $\left(\mathrm{kg} \mathrm{dm}^{-3}\right)$ and macroporosity $\left(\mathrm{m}^{3} \mathrm{~m}^{-3}\right)$. 

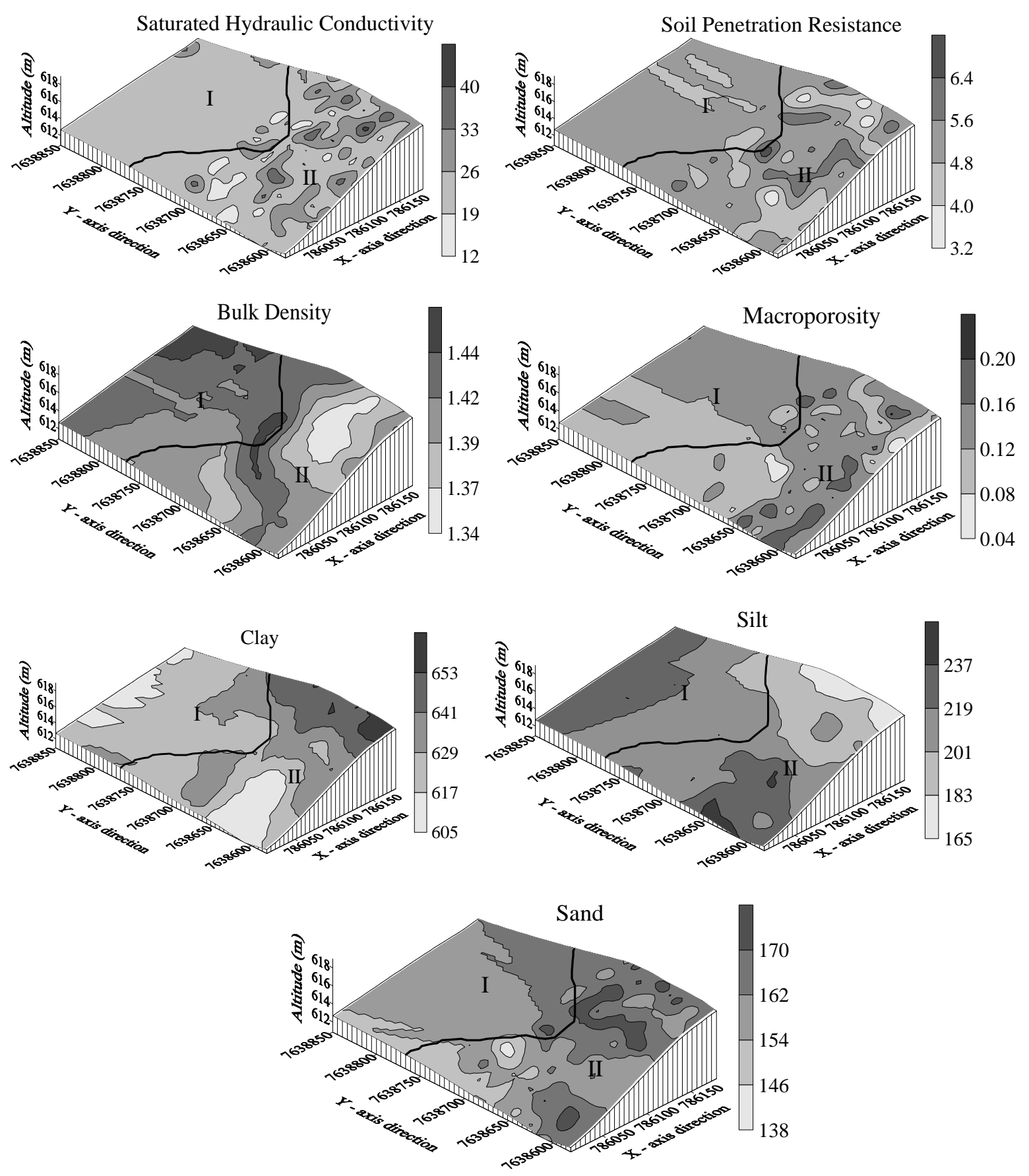

Figure 3 - Spatial distribution of soil physical properties at 0.2-0.4 m depth: clay, silt and sand $\left(\mathrm{g} \mathrm{kg}^{-1}\right)$; saturated hydraulic conductivity $\left(\mathrm{mm} \mathrm{h}^{-1}\right)$; penetration resistance (MPa); bulk density (kg $\left.\mathrm{dm}^{-3}\right)$ and macroporosity $\left(\mathrm{m}^{3} \mathrm{~m}^{-3}\right)$. 

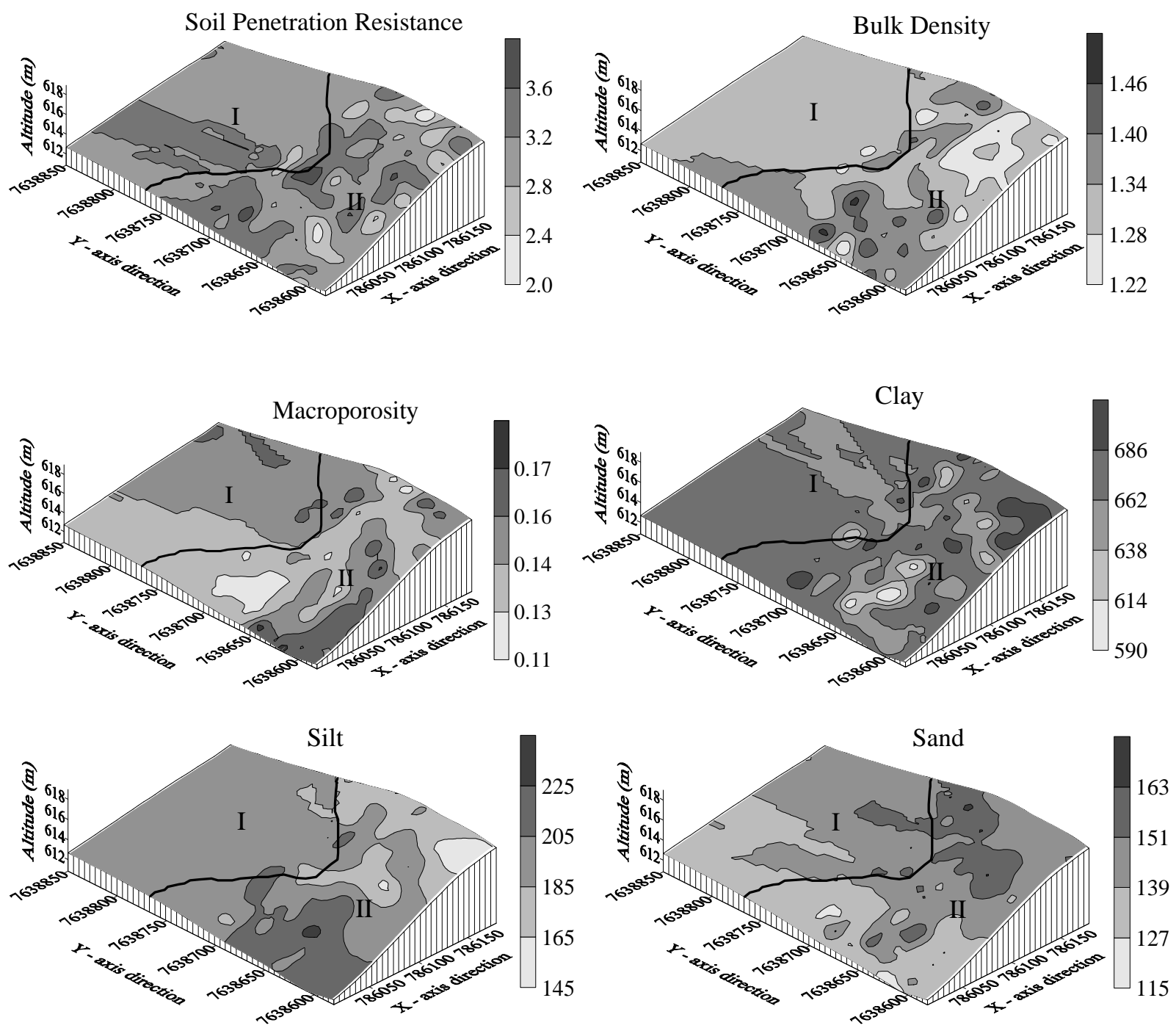

Figure 4 - Spatial distribution of soil physical properties at 0.4-0.6 m depth: clay, silt and sand $\left(\mathrm{g} \mathrm{kg}^{-1}\right)$; saturated hydraulic conductivity $\left(\mathrm{mm} \mathrm{h}^{-1}\right)$; penetration resistance $(\mathrm{MPa})$; bulk density $(\mathrm{kg}$ $\left.\mathrm{dm}^{-3}\right)$ and macroporosity $\left(\mathrm{m}^{3} \mathrm{~m}^{-3}\right)$.

The values of $\mathrm{Kt}$ and $\mathrm{Gb}$ crystallinity evaluated by the WHH and MCD agreed with the physical property values. The maps indicated that the $\mathrm{WHH}, \mathrm{MCD}$ and the $\mathrm{Kt} / \mathrm{Kt}+\mathrm{Gb}$ ratio had the maximum and minimum points in the concave and convex surfaces, (compartment II) and were spatially correlated with the physical variables.
Thus, Kt and Gb levels and the crystallinity level depended on the landscape shapes at this study scale. These trends shown by $\mathrm{Kt}$ and $\mathrm{Gb}$ crystallinity coincided with the landscape models and indicated an evident separation of the pedogenetic areas. 

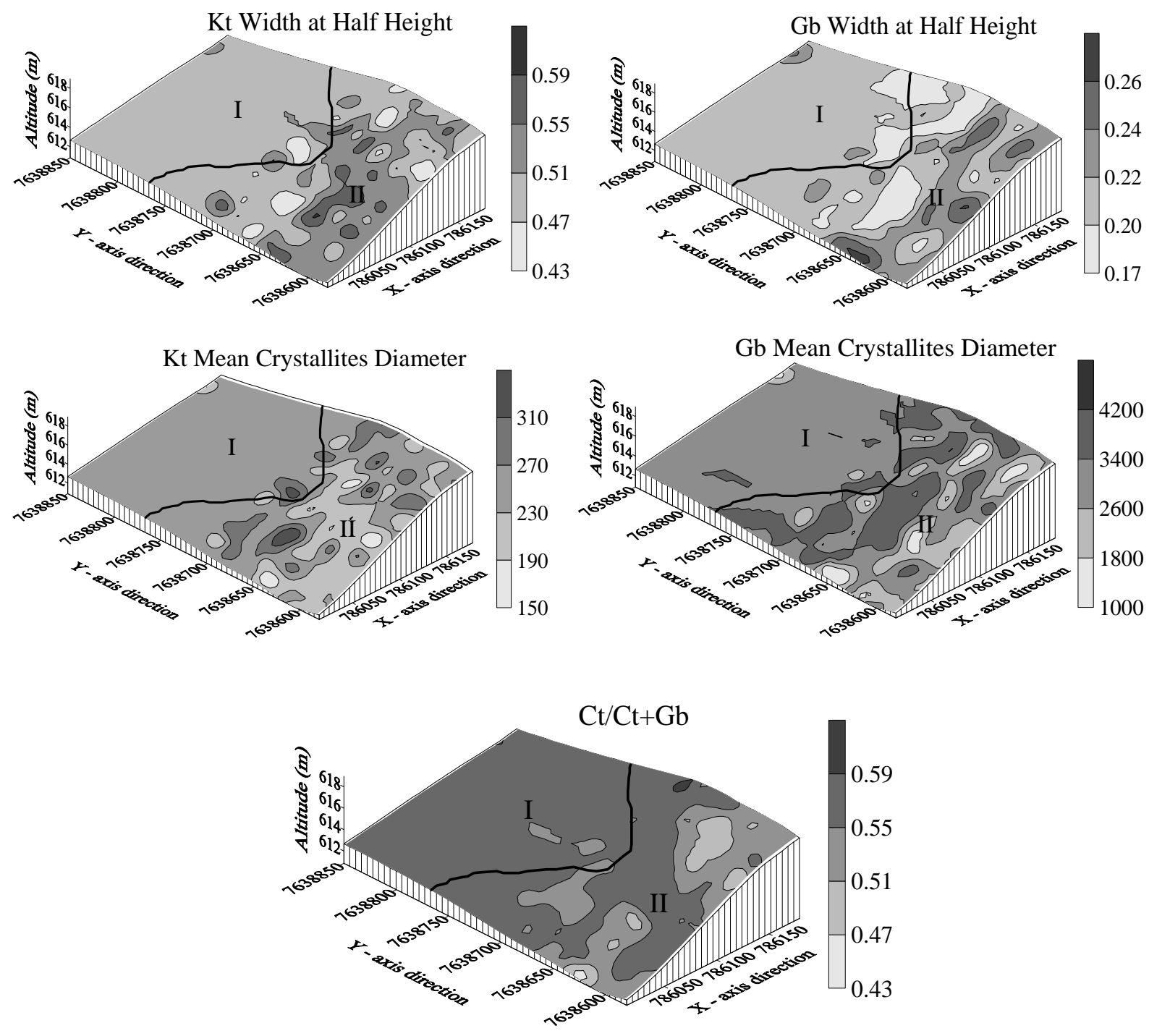

Figure 5 - Spatial distribution of soil mineralogical properties at $0.6-0.8 \mathrm{~m}$ depth: width at half height $\left({ }^{0} 2 \theta\right)$; mean crystallites diameter (nm); Kaolinite (Kt); Gibbsite (Gb) and $\mathrm{Kt} / \mathrm{Kt}+\mathrm{Gb}$ ratio.

The physical properties studied were affected by the $\mathrm{Kb}$ and $\mathrm{Gb}$ contents from the clay fraction. The $\mathrm{Kt} / \mathrm{Kt}+\mathrm{Gb}$ ratio (and consequently the $\mathrm{Kt}$ content) was higher in the compartment I (linear), where mean values of the bulk density and soil penetration resistance were also higher (Table 3). In the compartment II, Gb was predominant and probably caused the higher Ksat and macroporosity values. Ferreira et al. (1999) also found a strong influence of the clay soil on the physical properties of the oxisols from the southeast Brazil. The best mineral crystallization (lower WHH and higher MCD), especially for the $\mathrm{Kt}$, occurred in the compartment $\mathrm{I}$, which was linear shaped such that the soil was deposited in the plates. It might have influenced the higher soil penetration resistance and bulk density as well as the lower results of the macroporosity and Ksat in this landscape shape (Table 3). 
$\underline{\text { Table } 3 \text { - Soil properties in compartments I (linear) and II (concave-convex).. }}$

\begin{tabular}{lccc}
\hline Properties & Mean & Maximum & Minimum \\
\hline Compartment I & & & \\
${ }^{1} \mathrm{Hsat}\left(\mathrm{mm} \mathrm{h}^{-1}\right)$ & 20.78 & 59.17 & 4.17 \\
Penetration resistance (MPa) & 5.12 & 6.60 & 1.80 \\
Bulk density $\left(\mathrm{kg} \mathrm{dm}^{-3}\right)$ & 1.46 & 1.68 & 1.16 \\
Macroporosity $\left(\mathrm{m}^{3} \mathrm{~m}^{-3}\right)$ & 0.10 & 0.20 & 0.06 \\
$\mathrm{Kt} /{ }^{2} \mathrm{Kt}+{ }^{3} \mathrm{~Gb}$ & 0.58 & 0.72 & 0.34 \\
${ }^{4} \mathrm{WHH} \mathrm{Kt}\left({ }^{0} 2 \theta\right)$ & 0.48 & 0.72 & 0.29 \\
${ }^{5} \mathrm{MDC} \mathrm{Kt}(\mathrm{nm})$ & 261.62 & 577.59 & 157.01 \\
Compartment II & & & \\
Hsat $\left(\mathrm{mm} \mathrm{h}^{-1}\right)$ & 27.43 & 67.50 & 4.13 \\
Penetration resistance $(\mathrm{MPa})$ & 4.31 & 6.30 & 2.10 \\
Bulk density $\left(\mathrm{kg} \mathrm{dm}^{-3}\right)$ & 1.40 & 1.65 & 1.20 \\
Macroporosity $\left(\mathrm{m}^{3} \mathrm{~m}^{-3}\right)$ & 0.16 & 0.20 & 0.03 \\
$\mathrm{Kt} / \mathrm{Kt}+\mathrm{Gb}$ & 0.50 & 0.68 & 0.37 \\
$\mathrm{WHH} \mathrm{Kt}\left({ }^{0} 2 \theta\right)$ & 0.57 & 0.71 & 0.33 \\
$\mathrm{MDC} \mathrm{Kt}(\mathrm{nm})$ & 252.87 & 546.85 & 152.60 \\
\hline
\end{tabular}

\section{CONCLUSIONS}

The $\mathrm{Kt} / \mathrm{Kt}+\mathrm{Gb}$ ratio and the $\mathrm{Kt}$ relative crystallization level were higher in the compartment I (linear) than in the compartment II (concave/convex). Therefore, in the compartment I soil penetration resistance and bulk density were higher while the macroporosity and saturated hydraulic conductivity were lower.

The identification and mapping of the landform were very efficient for understanding the spatial variability and the cause and effect of the relationships among the studied soil properties. The variations in the relief shape led to the differentiated variability of the physical and mineralogical properties, of the soil.

\section{RESUMO}

Este trabalho teve como objetivo avaliar a influência das formas do relevo na variabilidade espacial de atributos físicos e suas relações com a mineralogia da argila de um Latossolo Vermelho eutroférrico, utilizando a técnica da geoestatística. Os solos foram amostrados nos pontos de cruzamento de uma malha, com intervalos regulares de $10 \mathrm{~m}$, nas profundidades de 0,0-0,2 $\mathrm{m}, 0,2-0,4 \mathrm{~m}$ e $0,4-0,6 \mathrm{~m}$ para os atributos físicos e 0,6-0,8 m para os atributos mineralógicos. Os valores médios para a densidade do solo e resistência do solo à penetração são maiores no compartimento I onde a relação $\mathrm{Ct} / \mathrm{Ct}+\mathrm{Gb}$ é relativamente maior, indicando a presença de maior teor de caulinita. No compartimento II a condutividade hidráulica e a macroporsidade são maiores, influenciados provavelmente pelo predomínio da gibbsita. Portanto, conclui-se que a identificação das pedoformas é muito eficiente para compreender a variabilidade espacial de propriedades do solo. Sendo que, as variações na forma da paisagem promovem variabilidade espacial diferenciada das propriedades físicas e mineralógicas do solo.

\section{REFERENCES}

Arshad, M.A.; Lower, B. and Grossman, B. (1996), Physical tests for monitoring soil quality. In: Doran J.W. and Jones A.J., eds. Methods for assessing soil quality. Soil Science Society of America (SSSA Special publication 49), Madison, WI, pp.123-141.

Bathke, G.R. and Cassel, D.K. (1991), Anisotropic variation of profile characteristics and saturated hydraulic conductivity in a ultisol landscape. Soil Sci. Soc. Am. J., 55, 333-339.

Bouma, J.; Stoorvogel, J.; van Alphen, B.J. and Booltink, H.W.G. (1999), Pedology, precision agriculture, and the changing paradigm of agricultural research. Soil Sci. Soc. Am. J., 63, 1763-1768. 
Cambardella, C.A.; Moorman, T.B.; Novak, J.M.; Parkin, T.B.; Karlen, D.L.; Turco, R.F. and Konopka, A.E. (1994), Field-scale variability of soil properties in Central Iowa Soils. Soil Sci. Soc. Am. J., 58, 15011511.

Castrignanò, A.; Giugliarini, L.; Risaliti, R. and Martinelli, N. (2000), Study of spatial relationships among some of a field in central Italy using multivariate geostatistics. Geoderma, 97, 39-60.

Chien, Y.J.; Lee, D.Y.; Guo, H.Y. and Houng, K.H. (1997), Geostatistical analysis of soil properties of mid-west Taiwan soils. Soil Sci., 162, 291-298.

Cressie, N. (1991), Statistics for spatial data. John Wiley, New York.

De Alba, S. (2003), Simulating long-term soil redistribution generated by different patterns of mouldboard ploughing in landscapes of complex topography. Soil Til. Res., 71, 71-86.

Dexter, A.R. (1987), Mechanics pf root growth. Plant Soil, 98, 303-312.

Djurhuus, J.; Hansen, S.; Schelde K. and Jacobsen, O.H. (1999), Modeling mean nitrate leaching from spatial variable using effective hydraulic parameters. Geoderma, 87, 261-279.

Ehlers, W.; Kopke, V.; Hesse, F. and Böhm, W. (1983), Penetration resistance and root growth of oats in tilled and untilled loess soi. Soil Till. Res., 3, 261-275.

Empresa Brasileira de Pesquisa Agropecuária (1997), Manual de métodos de análise de solo. $2^{\text {nd }}$ ed. Ministério da Agricultura, Rio de Janeiro.

Ferreira, M.M.; Fernandes, B. and Curi, N. (1999) Influência da mineralogia da fração argila nas propriedades físicas de latossolos da região sudeste do Brasil. R. Bras. Ciênc. Solo, 23, 515-524.

Hakansson, I. and Voorhees, W.B. (1997), Soil compaction. In: Lal, R.; Blum W.H. and, Valentin C, eds. Methods for assessment of soil degradation. CRC Press LLC, Boca Raton, FL, 167-179.

Isaaks, E.H. and Srivastava, R.M. (1989), An introduction to applied geostatistics. Oxford University Press, New York.

Liu, T.L.; Juang, K.W. and LEE, D.Y. (2006), Interpolating soil properties using kriging combined with categorical information of soil maps. Soils. Soil Sci. Soc. Am. J., 70, 1200-1209, 2006.

Journel, A.G. and Huijbregts, C.J. (1991), Mining geostatistics. Academic Press, London.

Miller, M.P.; Singer, M.J. and Nielsen, D.R. (1988), Spatial variability of wheat yield and soil properties on complex hills. Soil Sci. Soc. Am. J., 52, 11331141.

Oldak, A.; Jackson, T.J. and Pachepsky, Y. (2002), Using GIS in passive microwave soil moisture mapping and geostatistical analysis. Int. J. Geogr. Inf. Sci., 16, 681-698.

Onofiok, O.E. (1988), Spatial and temporal variability of some soil physical properties following tillage of a Nigerian Paleustult. Soil Till. Res., 12, 285-298.
Reynolds, W.D. and Elrick, D.E. (1985), In situ measurement of field-saturated hydraulic conductivity, sorptivity, and the $\alpha$-parameter using the Guelph permeameter. Soil Sci., 140, 292-302.

Salire, E.V.; Hammen, J.E. and Hardcastle, J.H. (1994), Compression of intact subsoils under short-duration loading. Soil Til. Res., 31, 235-248.

Schlotzhaver, S.D. and Littell, R.C. (1997), SAS: system for elementary statistical analysis. 2. ed. Cory: SAS.

Schoorl, J.M.; Veldkamp, A. and Bouma, J. (2002), Modeling water and soil redistribution in a dynamic landscape context. Soil Sci. Soc. Am. J., 66, 16101619.

Schulze, D.G. (1984), The influence of aluminium on iron oxides VIII. Unit-cel dimension of Al-substituted goethites and estimation of $\mathrm{Al}$ from them. Clay Miner., 32, 36-44.

Soil Survey Staff (1993), Soil survey manual (Handbook, 18). USDA-SCS. U.S. Gov. Print. Office, Washington.

Stolf, R. (1991), Teoria e teste experimental de fórmulas de transformação dos dados de penetrômetro de impacto em resistência do solo. R. Bras. Ciênc. Solo, 15, 229-235.

Strock, J.S.; Cassel, D.K. and Gumpertz, M.L. (2001), Spatial variability of water and bromide transport through variably saturated soil blocks. Soil Sci. Soc. Am. J., 65, 1607-1617.

Surfer for windows. Realese 7.0. (1999), Contouring and 3D surface mapping for scientist's engineers. User's Guide. New York: Golden software.

Trangmar, B.B.; Yost, R.S.; Wade, M.K. and Uehara, G. (1985), Applications of geostatistics to spatial studies of soil properties. Adv. Agron., 38, 45-94.

Troeh, F.R. (1965), Landform equations fitted to contour maps. Am. J. Sci., 263, 616-627.

Tsegaye, T. and Hill, R.L. (1998), Intensive tillage effects on spatial variability of soil physical properties. Soil Sci., 163, 143-154.

Utset, A. and Cid, G. (2001), Soil penetrometer resistance spatial variability in a ferralsol at several soil moisture conditions. Soil Till. Res., 61, 193-202.

Vieira, S.R.; Hatfield, J.L.; Nielsen, D.R. and Biggar, J.W. (1983), Geostatistical theory and application to variability of some agronomical properties. Hilgardia, 51, 1-75.

Warrick, A.W. and Nielsen, D.R. (1980), Spatial variability of soil physical properties in the field. In: Hillel D., ed. Applications of soil physics. Academic Press, New York, NY, pp. 319-344.

Zebarth, B.J.; Rees, H.; Walsh, J.; Chow, L. and Pennock, D.J. (2002), Soil variation within a hummocky podzolic landscape under intensive potato production. Geoderma, 110, 19-33.

Received: October 17, 2006; Revised: May 22, 2007; Accepted: May 21, 2008. 